\title{
Sustainability and the future: reflections on the ethical and political significance of sustainability
}

\author{
Christopher Groves ${ }^{1}$ (D)
}

Received: 31 August 2018 / Accepted: 16 April 2019 / Published online: 6 May 2019

(c) The Author(s) 2019

\begin{abstract}
Historically, concepts of sustainability have been articulated in response to a perceived crisis within modernist narratives about progress. As such, they are not just environmental concepts, but ethical and political ones. At the same time, they have often been accused of being too wedded to many of the same assumptions as these central narratives of modernity, and indeed inviting the hubristic mistakes of modernity to be resurrected in the form of pretentions to global stewardship or 'managing the planet'. I respond to some recent critiques of key conceptual elements encountered within sustainability narratives by articulating an approach to imagining sustainability that draws on D. W. Winnicott's concept of the 'holding environment', and which acknowledges the otherness of the future and of nature, while also affirming responsibilities towards both.
\end{abstract}

Keywords Sustainability $\cdot$ Futures $\cdot$ Alterity $\cdot$ Care $\cdot$ Attachment

\section{Introduction}

Ulrich Beck identifies a political project that he calls cosmopolitanism as the only legitimate response to a political and social condition in which human flourishing and suffering is bound up with human caused risks that affect both humans themselves and the non-human world. Cosmopolitanism, he proposes, is primarily 'a radical rediscovery and acknowledgement of the other', and, inter alia, of 'the otherness of the future' and 'the otherness of nature' (Beck 2005, 285). Beck identifies here two barriers to, but also opportunities for, imagining sustainability as a political and ethical orientation. How, as part of our conceptual construction of responsibilities and of political action, do we acknowledge (pay heed to, take care of, represent, recognise) the otherness of nature and of the future?

The link between concern for the future and concern for the earth is at the heart of sustainability thinking. In sustainability thinking, a sense that the future matters takes on a

Handled by Anne-Katrin Holfelder, Institute for Advanced Sustainability Studies, Germany.

Christopher Groves

Grovesc1@cf.ac.uk

1 School of Social Sciences, Cardiff University, Cardiff, UK specific weight, mediated by a rethinking of the relationship between humanity and nature that challenges many nowtraditional modernist narratives of material human progress. Yet how far does this bring nature as such into our ethics and politics, and under what framing? Does the concept of sustainability enter onto the scene at the cost of misrecognising the otherness of nature, that is, of framing nature solely in terms of its instrumental value for humans? This concern is mirrored by a similar concern about how sustainability frames the future in ways that still remain within the limitations of modernist ways of thinking, in which the future is imagined solely in terms of the continuation of present projects, which are then projected into the future in a way that colonises future possibilities.

An important distinction can be made here between two ways of orienting thought and action towards the future, between the future-for-the-present and the present-for-thefuture (Adam and Groves 2007). The easiest way to understand the idea of the future-for-the-present is through the example of future discounting, in which economic calculations are based on an assumed discount rate which ensures that the value of future benefits and costs is progressively reduced, such that it appears to make economic sense to seek to realise the benefits of a decision as soon as possible, and to push costs further into the future for others to bear. A central question about the relationship between 
sustainability and futurity, then, is to what extent sustainability thinking — as well as being potentially instrumental and, therefore, anthropocentric - is also present-centric. Perhaps not in the same way as future-discounting is, but more in the way that its emphasis on preservation and/or conservation privileges present evaluations of why non-human entities and systems matter over the emergence of future ones. There may, therefore, appear to be a tension between concepts of sustainability on the one hand, and Beck's vision of, cosmopolitanism, if sustainability does indeed orient human agency towards nature as primarily a stock of resources that must be preserved, and in addition towards dominant values in the present as a measure of what may matter to the future. The very idea of sustainability may, therefore, be ethically and politically suspect. First, because it may prematurely curtail attempts to understand why nature matters (in itself as well as for us), and second because it may fail to acknowledge how the recognition of whose values matter now is shaped by power inequalities, before then consolidating these inequalities by calling for the ongoing conservation of present values for the future.

In particular, concern for the future is often translated into the language of posterity, evoked by images of children. The scientific, ethical and political uncertainties which circulate around arguments about sustainability may thus be domesticated through entreaties to extend what is essentially parental care to future people, as expressed in the statement that one only borrows the earth from one's children. However, such images have particular political significance, insofar as they frame concern for the future in a form that privileges the perspective of heterosexual parents as the sole legitimate one (Johns-Putra 2017), and thus make it harder to publicly represent other possible framings of future-oriented concern, particularly in a present where political cultures are commonly structured by heterosexism and other forms of oppression (Seymour 2013). Such framings domesticate the otherness of the future, easing the 'terror of sublime infinity' (Johns-Putra 2017,2) stimulated by its vastness and unknowability. At the same time, the intermediate object of care here-nature, conceived of as that fundamental ground on which posterity will continue to depend-is also domesticated and drawn out of its unknowability into a frame of concern that filters care through the image of imagined descendants (de Shalit 1995). Domestication threatens to cross into instrumentalization, however. If nature is conceived of as that which sustains us-or our children and their children-does this not mean that we will (given the limits on our attention and practical capabilities) only care for whatever in nature we can currently identify as useful? Similarly, if we translate future-oriented concern into concern for our posterity, are we not reducing the scope of our supposedly cosmopolitan concern to what 'we' now consider to be important for 'our' children? In either case, what is valorised is the survival of what is valued in and for the present. The future-and nature-are defined through and for the present.

Alternatively, concern for the future or for the natural world may be expressed through a different temporal framing, the present-for-the-future. In some texts the future is imagined through an apocalyptic lens that is meant to motivate reflection upon values, practices and social structures which are currently held to be 'naturalised'-thus opening up space for trying to conceive of how these accepted elements might change. The future is no longer defined for the present; instead, the present is questioned for the future. Some suggest, however, that the limits of ethical concern here are once again ultimately limited to human survival: the addressee of apocalyptic narratives remains, it is argued, the individual human subject, politically privileged by present political rationalities, whose continuity must be assured (Fagan 2017).

In this paper, I map out some aspects of the historical emergence of these distinct ways of framing the future and nature, and show how they relate to each other as specific ways of enacting a temporal relation between present, past and future. I argue that these positions tend to rest on implicit misrepresentations of the relation between self and other and, therefore, between human subjects and nature. At the same time, recent critiques of the alleged anthropocentrism of these positions (such as those made by Fagan) commit, I suggest, errors of their own. They tend to afford ethical privilege to an unknowable otherness (Beck's absolute otherness of the future or nature) that, in its sublimity, cannot provide any concrete basis for orienting thought or action. As an alternative to both these dominant ways of understanding sustainability and to critiques thereof, I suggest that a genealogy of concern for the future and for nature that draws on phenomenological, development-psychological and feminist traditions of thinking about attachment and care can provide a distinct basis for thinking about sustainability. It allows the otherness of nature and of the future into the sphere of concern as necessary ingredients of any concernful engagement with the world, without at the same time positing either as purely other, as pure, unknowable alterity.

\section{Progress and modernity: the future for the present}

Nature conceived of as a free input into socially-organised production processes formed what Marshall Berman represents as the modern 'Faustian' view of nature, as raw material for ceaseless human development (Berman 1983). This characteristically modern prometheanism is also reflected in more avowedly political and utopian ideas 
of an open future (Adam and Groves 2007), which centre on secularised promises of continually refounding community around a vision of a better world. A new ethical and political concern with the future, with ending the past and instituting something new and unheard of in its place has been invoked as a defining modern mode of temporality, in intellectual history (Schneewind 1984) but also in sociology (Giddens 1999). Modernity is thus seen as unique because of its orientation towards the future, rather than towards the past. This periodisation simultaneously constructs and excludes from the community of modernity (Osborne 1995) other communities, such as the medieval and the ancient, on the basis of their divergent past-oriented or cyclical temporalities.

This modernist construction of the future is dependent on ideas of the transformability of the world, which reproduce idealist assumptions about the relationship between imagination and material nature (Adam and Groves 2007). They draw upon particular historically-contingent knowledge practices. Nature becomes gridded by calculative rationalities, defined as fuel for universal human ascent. With the 19th century growth of the 'social state', responsible for economic policy but also social policy, progress became increasingly understood in material and, moreover, quantitative terms - what might be called the "mechanisation [Technisierung] of the future (Hölscher 1999) alongside the standardisation of nature. Metrics such as population growth, average life expectancy, or gross domestic product (GDP) formed elements around which governance regimes that enshrine governance by numbers gained legitimacy. As states increasingly took responsibility for the health and education of their citizens, the legibility and, moreover, the standardisation of their territories become more important. Qualitative differences between settlements and regions had to be rendered recordable, comparable and commensurable in terms of universal metrics (Scott 1998). The contribution of industry and technological innovation to ensuring material betterment also gradually became more important.

Expectations of material improvement in quality of life reached a head in the period after WWII within industrialised nations. At the same time, however, earlier challenges (Bonneuil and Fressoz 2016) to the hegemony of conceptions of material progress were being repeated. Concerns about the unforeseen and unwanted consequences of technological and economic development and particularly their impact both on the biosphere and non-industrialised nations were widely voiced. Carson's Silent Spring (1962) and the Club of Rome's Limits to Growth (1973) report both had significant cultural impact. The experiences of people of colour and other groups living near polluting infrastructure were articulated through movements for environmental justice (Schlosberg and Carruthers 2010).

\section{Futures for the present versus presents for the future: conceptualising sustainability}

The emergence of discourses of sustainable development and environmental management can be understood against this backdrop. While ideas of sustainable resource management have a long pedigree reaching back to the 19th and even 18th centuries (Bonneuil and Fressoz 2016), it was arguably in this period that 'the Environment' as a whole became a new object of bureaucratic management (Cooper 1992), objectified and drawn into the purview of the administrative state just as earlier the social had been. The knowledge practices of ecologists, zoologists, botanists and others became enrolled within this governance project, to standardize knowledge practices for measuring and comparing impacts of collective human activity upon the natural world. The biophysical world is no longer simply raw material for human progress, but becomes conceived of as a complex entity, still set over against humanity (and thus isolable as an object of management) but posited as an ensemble of essential support systems (Goodland 1995).

As environmental impacts are transboundary in nature and occur within complex systems, they point towards the creation of global governance institutions, like the Intergovernmental Panel on Climate Change (Beck 1995). The more complex and daunting the project of drawing nature into the sphere of governance became, the more the need for legibility became urgent. As a result, the need for governance by numbers became ever more central to establishing a politics of the environment. Parts per million of $\mathrm{CO}_{2}$, the Simpson and Shannon indices of biodiversity (Spellerberg and Fedor 2003), and the nine planetary boundaries (Rockström et al. 2009) became means through which sustainability policies were articulated and justified. The institutions that characterise modernity, and the practices associated with them, have been said to have thus undergone a 'reflexive' moment (In Beck's terms), striving to contain modernity's own unintended consequences.

\section{Management narratives}

Taking the future into account, and orienting oneself towards it as a central element in determining what one should do, is part of both progress narratives and what we might call reflexive 'conservation' narratives. In each case, the moral weight accorded to the future is articulated in different ways, but in each case, the non-human world (configured as 'natural capital' or more recently as 'ecosystem services') becomes the fulcrum around which this weight turns. Robert Solow responded to the moment 
of reflexive modernisation by defending the accumulation of capital as the best way of ensuring that future generations inherited enough resources to fulfil their needs. Importantly, he argued that capital here could include natural resources, financial resources but also technological resources substituted for natural ones (Solow 1974). In other words, the development of technology should be seen as a way of providing additional resources that may replace and even improve on natural ones in some cases (Northcott 2013). Such views are accompanied by an estimate of the social discount rate that should be applied to expected costs and benefits of policies, given the assumption that people in the future will be better off (thanks to continued material progress). Complementary views are also expressed by some proponents of conservation, where conservation is seen as the preservation of natural capital for the benefit of people now and in the future (Pinchot 1998, 76-77).

Bryan G. Norton has named the animating spirit of such responses the 'Grand Simplification' (Norton 2005), in which all potential future outcomes are both rendered down into material amenable to one metric (measurement of capital) and weighed against the primacy of present interests. Continuation of current trends towards material growth is seen as both natural and desirable, but this simply enshrines present pattern of consumption as unquestionable so long as the future is like the present, but more so, characterised by ever-increasing levels of economic activity (Fioramonti 2013). The move Solow recommends therefore projects futures from the perspective of the present, based on the continuation of past trends and the preservation of present interests. As Fagan $(2017,232)$ puts it, such positions bring the future into the present only insofar as they ensure that the "future is instead occupied by the projection of the present and so is not futural [i.e. not other] at all'. Other attempts to present a managerial solution to the unintended consequences of narratives of progress run into similar difficulties, even if they are explicitly critical of the kinds of position defended by Solow.

More recent (and contested, as we shall see in the next section) conservation narratives often seek to preserve what formerly may have been defined as natural capital by identifying productive powers of non-human nature that have economic value insofar as they contribute to human wellbeing, a value which can be (speculatively) totalled in order to achieve a degree of considerability for nature (Costanza et al. 1997). In this way, it is hoped that planning futures could incorporate economic relationships within a broader context of productive relationships that sustain natural systems, rather than enforcing the separation between inert non-human nature and a human economy geared to material progress measured in terms of financial value productivity.
Valuing ecosystems in this way can be seen, however, as still part of commodification, with the effective pricing of nature extending property rights further over it, rather than curtailing such developments. The commodification of nature translates relationships of one kind (sui generis complex interdependence between non-human and also human entities) into exchange value, with one arbitrarily demarcated 'service' treated as being effectively substitutable for any other in economic terms (Gómez-Baggethun and Ruiz-Pérez 2011). Conservation narratives have thus been interpreted as modulating, but not ultimately restraining the drive to treat nature as an inert input. And even if economic valuation is just one input into a broader, more qualitative valuation, some object that this still defines the value of nature predominantly through the lens of human interests. Nature is only made to matter insofar as it materially supports the survival of our descendants. Elements of natural systems that appear to have no material value for our own survival do not matter.

Even if we shift from a Faustian to a managerial view of nature, we thus remain caught within a set of social relations through which the meaning of nature is framed (Bookchin 1980). Even if questions regarding responsibility shift focus to include the non-human world, sustainability remains a human-centred concept, concerning the conservation of what we believe matters to our survival. As Fagan puts it, the future is 'occupied by the projection of the present'. The future is extrapolated from what we know of the past (data, trends) and present (interests). From modernist progress narratives to sustainable management narratives, the future remains framed for the present - a present future (Adam and Groves 2007).

\section{Apocalyptic narratives: revelation and judgement}

The emergence of management narratives was also coeval with the emergence of more radical narratives regarding our relationship to nature - and to the future. While both these kinds of narratives had historical antecedents (Bonneuil and Fressoz 2016), something novel about their late 20th century forms was the conditions in which they emerged, a cultural moment of what I called earlier (after Beck) reflexivity towards the fundamental assumptions that underlie modernity. More radical narratives recognise within this moment a deeper crisis, and accordingly alter their orientation towards the future and towards nature.

Often, such narratives take on an apocalyptic form, employing prophetic language bolstered by scientific data on potential destructive trajectories of socio-technical and biophysical change. Futures that disrupt or completely erase the possibility of modernist progress are imagined. Biospherical collapse due to runaway climate change, biodiversity loss through species extinction, human population growth 
beyond supportable levels and other worst case scenarios are projected. Further, they typically embody the other central meaning of apocalyptic narrative, that of judgement as well as revelation (Northcott 2013). Dystopian future presents are constructed in the form of scenarios to shine a light on what is wrong with the present, mirroring in the process some trends in science fiction literature.

Stories such as John Brunner's The Sheep Look Up (1977) describe near-futures in which a variety of rebound effects combine with social inequalities to degrade or destroy human civilisation. Such narratives limn what might appear to be fundamental flaws in the relationship between humans and nature. The meaning of the present is here defined through future possibilities, not the other way around. Science fiction has been interpreted as reflecting aspects of the present, but also employing the estranging device of some novum (typically technological innovation) that enables certain aspects of the familiar world to be reflected in a future mirror, revealing unacknowledged truths about the present (Kitchin and Kneale 2001). Deep ecology echoes such narratives by prophetically articulating revelation and judgement derived from the future as a call to lay bare and overcome culturally-embedded habits of mind in a 'substantial reorientation of our whole civilisation' (Naess 1990, 45).

A new ethics is then called for, to replace the anthropocentric orientations of contemporary societies with biocentric egalitarianism, positioning humans as 'plain citizens' of nature (Watson 1983). From this perspective, life itself in its multiplicitous expressions has intrinsic value, and no form of life (including humans) can be assigned superior moral value, no matter what capacities it possesses. The human power to transform the world does not in itself grant humans any right to do so. What does mark humans as special is their ability to perturb the webs of mutual interdependence that constitute the biosphere, creating destructive consequences that also eventually rebound back upon them. Humans therefore require nothing less than a cultural revolution in consciousness, one which promotes humility in the face of nature, to avoid destroying themselves and possibly also the rest of life on Earth.

\section{The future (and nature) as wholly other}

The concept of sustainability is the result of a reflexive push back from within modernity against modernity itself. Sustainability acknowledges but also tames the threat of apocalypse, offering the promise of refounding a coming global political community on a renewed narrative of qualitative. Things may continue to get better-so long as we are careful. Deeper reformation or even overthrow of present habits, practices and institutions is called for by other narratives, as in stories of apocalypse or the perspectives of deep ecology.
But in either case, straining to represent the present for the future, as responsible to the future, can be seen as returning, once again, to representing the future as a continuation of the present by other means.

Fagan (2017) argues that apocalyptic narratives necessarily fall short of recognising the otherness of the future and the significance this has for any ethical and political discourse of futurity in the present. The problem, she suggests, is that any concrete normative guidance in the face of an uncertain future must inevitably reflect the constitution of the 'subject who is projected to inhabit this future' (239), and thus reflect also the conditions under which the subject is produced in the present. Instead of hurriedly providing new normative guidelines in the face of impending potential anthropogenic disaster, an appropriate alternative stance would, in Derrida's words quoted by Fagan, be to 'let the future have a future' (239), and open 'a space for responsive engagement' (238) with it. Insofar as there is an ethics involved here, it would be one which can be identified (following Zygmunt Bauman) in 'an ethics of self-limitation'. This minimal normativity of humility in face of the future (which mirrors the language of deep ecology) would thus avoid the risk she sees as implicit in any attempt to codify ethically and/or politically responsibilities to the future of 'erasing [the future] altogether' (239). Uncertainty, she proposes, will thus become the material for ethics, rather than a barrier to it.

\section{Reconstructing sustainability: the non-human world as constitutive of a 'holding environment'}

One of the positions Fagan indicts with the charge of "nullifying alterity' by projecting the future into the present is the one I set out in Groves (2014), which explores how phenomenological, developmental-psychological and feminist accounts of attachment and care can reorient discussions about the place of futurity (and sustainability) away from futures-for-the-present. I wish now to revisit this argument in responding to the problem on which this paper has focused - the ways in which sustainability appears to reproduce certain features (anthropocentrism and present-focus) of modernity while also claiming to escape its limitations. Independently, Johns-Putra and Fagan point out how sustainability discourses respond to the reflexive moment within modernity by seeking to reform the culture of modernity itself. However, they claim mere reform must necessarily be inadequate. Fagan (2017) calls instead for an ethics and politics that acknowledges the radical alterity of the future, and the ways in which imagining the future inevitably reduces this alterity to a reflection of the present, even if straining towards imagining the present for the future. In rehearsing 
here some key aspects of arguments from Groves (2014) I want to outline what I believe Fagan, and Johns-Putra, get wrong about the difficulties of bringing futurity and uncertainty into ethics, and to suggest why following Beck in positing the radical alterity of the future as the basis of ethics and politics is a step it is not necessary to take. An alternative way of understanding the interdependence of humanity and nature that concepts of sustainability try to articulate can give us a basis for understanding the ethical and political significance of sustainability differently. The concepts of attachment and care are important here, but rehearsing their precise connection is important to avoid associating them too closely with images of parental relationships, which, as I explicitly argue in Groves (2014, 221-222, n.7), are actually inappropriate for understanding the ethical significance of futurity and of nature.

\section{Attachment and care beyond the human sphere}

The relation between human subjects and the world experienced as outside, other to, or not reducible to the lived experience of the subject cannot be assumed to be a simple, fixed binary one. Developmental accounts of subjectivity, and in particular those produced from object-relations and attachment psychology, show how differentiation from but also identification with the external environment are central dialectical elements in the gradual emergence of subjectivity. Further, they recognise that physical and psychic vulnerability, together with interdependence and dependence are fundamental aspects of the finitude of human beings-a human condition (in Hannnah Arendt's sense) rather than a human essence. Vulnerability is physical and psychic, a dynamic which involves bodies and selves. Attachments to others - beginning, developmentally speaking, with caregivers-form the flexible and relational armature within which subjects are constituted (Groves 2014, 99). For psychologists of attachment like Winnicott (1991) differentiation and identification are moments which resolve out of affective transactions conducted through a transitional or shared space which is neither fully subjective nor objective, but out of which the meaning of self and other is produced.

For infants, good attachments help create ontological stability and security by assisting with the development of emotional regulation, transforming potentially disruptive and uncontrollable affect into emotions directed at defined objects. Stability and security here do not denote rigidly fixed boundaries for the self. Instead, for there to be subjectivity at all there needs to develop an emotionally-contoured space-a holding environment-in which affects can be transformed and played with, thus forming the basis of creative transformation of the world and self, conducted through the disruption and remoulding of the boundaries between the two. The structure of this dynamic self-other relationship is dialectical, expressed in the way that attachment objects come to matter to the self. The other here is valued by and valuable to the self in a particular way. As attachment object, the other is constitutive of the self. But it is so only insofar as it remains other in the sense articulated by Fagan when she describe Levinas' concept of the other 'completely other and impervious to my powers of comprehension and control' (Fagan 2009, 7), as ultimately unknowable to the subject and uncontrolled by it, as a source of surprise (Sayer 2011, 123). In this sense, an evolving attachment relationship is structurally similar to that of friendship as analysed by Aristotle, which embodies a category of value central to the Greek concept of eudaimonia ('flourishing'). The other as friend is recognised by Aristotle as of constitutive value to the subject. The other is of constitutive value in this sense if its wellbeing is ingredient in the wellbeing of the subject (O’Neill 1993, 23-24). It continues to endure as uncontainably other within the relation and only insofar as it does so is it valued by the subject.

It is important to appreciate how attachment enacts relationality to understand the ethical and political significance of both futurity and the non-human world. This relationality is asymmetrical, yet also two directional, in a sense I shall return to in a moment. It also extends further than to human others. The Other as conceived of in Levinas' philosophy is a human individual. The radical responsibility not to kill or harm the Other he places at the foundation of ethics is supposed to undercut the indifference to the other that Levinas traces in modern ethics and politics. This, however, already assumes a certain model of subjectivity (Fagan's 'modern subject'), and in responding to and critiquing such a version of subjectivity, it inevitably defines itself partially through it (Gottlieb 1994). A genealogical and historical account of attachment puts us on a different track. If we follow this track, then the isolation and indifference that is often seen to characterise the modern subject is shown to be only a contingent and culturally particular achievement of certain subjects-for example, as a withdrawal response to attachment loss, or to attachments that are felt to imperil the self (Benjamin 1990).

Attachment connects, from an early developmental stage onward, places, non-humans, and things (possessing, for Winnicott, the capacity to 'enchant' the human world) to human subjects. These also become part of the 'convoy' of attachments (Antonucci and Akiyama 1994) amidst which selves emerge early in life, except of course where such attachments are made unavailable-due to displacement, violence, or lack of care. Attachments as constitutive values establish what might be called an 'implicit solidarity' (Groves 2015, 857) between subject and the human but also non-human world, one which means that the subject of good attachment is not 'cast into the world' as an isolated individual but is instead 'cradled' within it (Bachelard 1969, 7), 
held together by it. Later in the developmental process, other attachment objects-e.g. practices, institutions and idealscan become important ingredients of the shared space or holding environment of implicit solidarity between self and world.

None of these others confront the subject simply as static, sublime Levinasian other who embodies an infinite-and infinitely terrifying-demand. Care is both disposition and practice (Engster 2007; Ruddick 1980), a response to the fundamental relationality of the human subject and its attendant psychic and physical vulnerability that renders itself concrete in attentive and respectful taking care of the needs of the other. But it is also thereby an attempt to sustain the web of attachments that create the relationality of a shared transitional space, in which the production of meaning is possible (Groves 2014, 117). As such, it cannot be imagined as primarily parental, in contrast to what Johns-Putra (2017) maintains, as it extends beyond relations between humans. This shared space is made from relationships that are asymmetrical, yet which also run in two directions: attachments are constitutive of subjects; subjects are called to respond to their attachments. The shared space is one of uneven and non-symmetrical interdependence. It through this shared space that the psychological components of processes of recognition (and indeed the relational logic of recognition itself) are laid down, though this subject lies beyond the scope of this paper.

Within the shared space, futurity is the horizon of the still-to-be-determined collective fate of subjects and their attachments-which first introduces the primary ethical and political question, 'how shall I/we live?' Attachment implicitly contains within it a wish for a future that may or may not be possible to fulfil (Berlant 2011), a wish to sustain the shared space as a source of meaning, and thus also orients the self towards the future flourishing of significant others. These others-including places, objects, practices, institutions and even ideals-have to be understood as dramatis personae within linked narratives, for whom things can turn out better or worse. Understanding what 'better' and 'worse' mean here is impossible without relying on knowledges of various kinds, expert and lay. Without determinate ways of imagining the future, it is impossible to actually respond to the otherness of the other who is the object of care. The other person who I nurse through illness, the landscape I fight to protect, the ideals of justice or equality I struggle to see realised-all these are constitutive of a common space that is productive of the meaning of the world. But this meaning only emerges because for all these attachments, things could go better or worse in determinable ways (recovering or sickening, being despoiled or flourishing, being vindicated or betrayed). The future as horizon of meaning is projected through the shared space of attachment relationships. Ultimately, it is the possibility of the shared space that is the object of care itself, which keeps the future open (and, therefore, to some extent unknowable).

Attachment and care are not just the connective tissue of ethical life. They also open up a difficult path between private and public life, between ethics and politics. Attachment objects are-implicitly or explicitly_public things, constitutive of a holding environment that is shared more widely and which shape the (not necessarily universally) shared commitments through which we enter into political life, into a life where public objects of attachment need tending (Honig 2012, 65). Care, in the sense outlined here, is thus not simply a motivational slogan addressed to individuals (pace Fagan 2017). Care is a morally but also existentially necessary component of interdependence and vulnerability (Engster 2007). It may not always be exercised, or even be exercisable, given surrounding conditions. But its necessity remains. To tend to private or public objects of attachment enjoins us to follow paths that criss-cross back and forth between the private and public realms, in the forms in which they have been historically constituted. Speaking up for urban parks connects us back to the individual and personal meanings through which the common fate of these places and those who enjoy them are woven together. Caring for a sick relative connects us to health institutions, to the practices and rules that define how professionals within them operate, and to the funding decisions which shape how these institutions themselves (for which we may feel a sometimes angry and frustrated affection, as is often said of the National Health Service in the UK) are materially sustained. It enjoins us to know and critically examine the wider structures we rely on. Care, as a moral and existential necessity, requires us to sustain private and public holding environments, and in doing so, extend ourselves deeper into relationships between those others for whom we care and further out into the material and psychic relations that sustain them. It requires attentiveness to attempt to understand the needs of others. This implies restraint insofar as one should not assume one already knows the other's needs, but also assumes these needs can be understood, if never perfectly. The difference between the other's past and his/her/ its future represents a gap within which a response can be improvised. Care thus represents a programme of ethical and political enlargement, not self-limitation (Baier 1995, 19).

How does this orientation towards futurity, born of attachment, connect us to nature, and thereby to the future beyond our own personal lives and the attachments which sustain them? Care begins from human concerns and what experience has taught us to value. The fact of attachment is thus contingent. But attachment and care themselves are not. Insofar as there is ethical or political motivation at all, they revolve around private and public things which are generative of meaning and which call us to individual and collective action. Just as better and 
worse forms of attachment, and better and worse forms of care in response to attachment, can be identified by understanding individual biographies, better and worse forms of collective attachment that enable or deny ethical and political agency to specific actors can be identified through an understanding of history. The question is then to what extent these succeed in recognising others' needs, given that recognition is never perfect, as McLaren (2017) points out, and also to what extent they acknowledge the wider interdependencies that sustain those who are their subjects (Marris 1996). Nature enters into the sphere of value defined by care, not primarily as an instrumental resource, but as a constitutive other. The dependence of human society on this other is primarily and experientially felt through processes like place attachment, not through more abstract forms of knowledge that confirm its instrumental value. The meaning of the non-human world comes from repeated singular encounters, and only later perhaps is broadened through attachment to ideals that articulate background reasons about why the non-human world matters.

The non-human biosphere is thus a constitutive other within the holding environment in which subjectivity first emerges. It can only provide this 'service' to the subject, however, insofar as it remains other, i.e. is encountered in forms that reveal themselves but also, as living and nonliving entities, recede and remain within themselves and in their complex relations to the rest of the biosphere, never wholly graspable. Possessing their own good, the entities and relationships of which the biosphere is composed can be tended-and shaped. How they should be tended and shaped is dependent, first, on situated practices that embody (or fail to embody) the virtues or dispositions of care. Second, it is dependent on norms. But determining what norms apply is a project of innovation and experimentation, as it is dependent on the outcome of a transactive play of boundaries of knowledge and action that can be more or less attentive and respectful. But the outcome of such interactions has to be judged according to how they actually enhance or degrade the narratives, as we struggle to understand them, to which belong the things tended and for whose needs we claim to speak. The very otherness of these others means that, ultimately, the sphere of tending will be more or less radically circumscribed, even if we aim to extend it, as our knowledge will necessarily become more limited the further it seeks to extend in space and time. But such a response is demanded by both our attachments and the systems and structures, human and nonhuman, on which they in turn depend. Responsibility is not infinite in the sense Bauman (1993) stipulates. Infinite responsibility is simply responsibility without responseability. A determinate response, enacting practices which may fall short of the norms we use to make sense of and evaluate them, is necessary. Violence towards the other is the risk of response, but to not respond, and instead simply shrink back from an otherness to which we are always already related is also violence (Lloyd 2008).

In this way, drawing on the account of attachment and care given in Groves (2014) the non-human world does not occupy the same position as it does in the various ways of thinking about sustainability we have explored. It is not conceptualised solely as the material basis for sustaining the human future (futures for the present). Nor are its possible futures the material for worst-case scenarios through which judgement can be passed on (some) present values (presents for the future). Instead, it the ultimate support for human care, but also a meaningful and meaning-conferring other within the sphere of human care that also exceeds its reach. As the latter, it is thus ingredient in the holding environment through which the future first becomes an issue for human beings, and which existentially places us in a position that demands our care. The common fate of selves and others related through the holding environment makes the intangible future tangible and actionable, while also commending to us a humility that is nonetheless attentive and active, committed to translating care for the needs of the irreducibly other into action.

\section{The holding environment as relation to the future}

This presents us with a different way of beginning to articulate a politics and ethics of the futurity which sustainability needs to embody. If the future is wholly other in the sense that no determinate relation to it is possible or legitimate, then the only relation to it can be a static one, frozen in the face of an infinite demand to hold back. All imagination and representation extended forward to grasp the future are indicted, meaning that the only ethically appropriate actual response would be to 'decreate' the self (Rose 1993, 217), to disavow thought and agency in face of the Other to whom all representation must necessarily do unjustifiable violence. But if the otherness here is an intrinsically unimaginable future which cannot be represented in any way without illegitimately capturing it in the discursive grids that frame the present, then all that is left is to disavow the political cultures of modernity and simply await the future, in the hope of an 'absolute beginning' (Bauman 1993, 93), waiting for a new ethical and political community to be founded. This, however, is a stance which ironically remains caught in that characteristically modern way of relating to the future that treats it as the end of the past and the coming of the unheard of novum (Babich 2013) —only at the same time forswearing all agency, and instead simply awaiting this end and new beginning.

By contrast, the holding environment of attachments and their supporting conditions embodies connective tissue 
of an always contested and partially articulated world, but in doing so, gives us the capabilities to anticipate not only the futures of those things we care about, but to extend and transform the scope of what we do care about as we come to understand the dependencies of the objects of our care. In doing so, private and public things serve as the material for narratives out of which private and collective identities emerge. They offer us the basis for a 'political morality of uncertainty', of anticipating, not the specific objects which future people will care about, and thus simply reducing the future to the projection of the present, but of anticipating instead the kinds of structuring relations through which any care can be expressed as good enough care, to attachments which promote genuine modes of self-determination and solidarity with the human and non-human worlds (Groves 2014, 161-62). This positions future people, neither as submerged within the otherness of the future, nor as simple reflections of us, but as potential and always other cocreators of something ethically and politically valuable (de Shalit 1995, 118-119), a world composed of things meaningful both privately and publicly. While these things and the holding environments that contain them are historically contingent, some such worlds are nonetheless necessarily better than others.

This is why Fagan is incorrect when she states that a carebased ethics and politics of futurity is based on a concept of interdependence that 'is nonetheless predominantly unidirectional' $(2017,236)$. Caring about the future is asymmetrical, but then so is all care. The future remains, however, the dimension of the present in which the narratives of what we care about shall be played out, and where their continuing worth (and the meaning of our own lives) will also be evaluated (O'Neill 1993). Anticipating the care of others is also trying to anticipate what our legacy will mean to them, a difficult but necessary task. Again, simply reverting to an ethics of self-restraint that seeks to avoid positing any future for fear of illegitimately representing the unrepresentable here is simply to accept the violence that has already been done to the future in the name of the present.

\section{Conclusion}

Discourses of sustainability arise out of, and preserve within them, a dilated cultural moment in which core norms and practices of modernity undermine themselves, riven with anxiety that erodes the ways in which modernity's habits of mind and knowledge practices constructed the relationship between past and future. Different attempts to articulate how sustainability might be an anchor for new practices and norms, as we saw, take up different ways of reconstructing this relationship, in more or less radically reformatory ways. Anxiety is always an existential accompaniment, as Gillian
Rose has argued, to experiences where practices and norms no longer fit with each other (Rose 1996). Disruptive experiences of this kind are exemplified by bereavement, typically understood as a loss of attachment which lays waste the relationship between self and world, requiring each to be reconstructed (Nussbaum 2003). 'How should one live', and 'what is permitted' are collective questions and anxieties at the same time as personal ones, questions which demand that practices evolve and norms be articulated around them in ways that fit together once more, after an experience of loss. Sustainability contains within it conflicts between the limits of knowledge and the need of ethics and politics which appear irresolvable.

I have advocated in this paper that to recognise and work through this anxiety cannot be done by doing as Beck advocates and simply positing the future as alterity, as this effectively denies the relationship to the future that is already part of our historical experience. Instead of articulating sustainability as the basis of a new, abstract global community somehow united in self-restraint or in a new, technologically-mediated commitment to progress, it is necessary to recognise that present subjects are related to the future unevenly and differentially through attachments and commitments that anchor them in the political field here and now. These commitments to private and public things shape and orient their individual and collective capabilities for action. It is only by asking to what extent these attachments build relationships that can sustain enlarged care for others now and in the future that sustainability can be fleshed out. Making sustainability a concrete way of working through the multi-decadal collapse of progress narratives requires the improvisation of shared practices that effectively embody care for the world and solidarity with future people, and the articulation of norms that will help us both locate ourselves as performers of these practices, and trouble us with their insufficiency as ways of expressing our responsibility to whoever comes after us. Responsibility is irresponsible unless it is transformed into an actual response.

Open Access This article is distributed under the terms of the Creative Commons Attribution 4.0 International License (http://creativeco mmons.org/licenses/by/4.0/), which permits unrestricted use, distribution, and reproduction in any medium, provided you give appropriate credit to the original author(s) and the source, provide a link to the Creative Commons license, and indicate if changes were made.

\section{References}

Adam B, Groves C (2007) Future matters: action, knowledge, ethics. Brill, Leiden

Antonucci T, Akiyama H (1994) Convoys of Attachment and Social Relations in Children, Adolescents, and Adults. Soc Netw Soc Support Childhood Adolesc 1994:37-52 
Babich B (2013) Angels, the space of time, and apocalyptic blindness: on Günther Anders' endzeit-endtime. Ethics Polit 5:144-174

Bachelard G (1969) The poetics of space. Beacon Books, Boston

Baier A (1995) Moral prejudices: essays on ethics. Harvard University Press, Harvard

Bauman Z (1993) Postmodern ethics. Blackwell, London

Beck U (1995) Ecological enlightenment: essays on the politics of the risk society. Humanities Press, London

Beck U (2005) Power in the global age: a new global political economy. Polity, Cambridge

Benjamin J (1990) The bonds of love : psychoanalysis, feminism and the problem of domination. Virago, London

Berlant L (2011) Cruel optimism. Duke University Press, Durham

Berman M (1983) All that is solid melts into air : the experience of modernity. Verso, London

Bonneuil C, Fressoz JB (2016) The shock of the anthropocene: the earth history and us. Verso Books, London

Bookchin M (1980) Toward an ecological society. Black Rose Books, Montreal

Brunner J (1977) The sheep look up. Ballantine, New York

Cooper D (1992) The idea of environment. In: Cooper D, Palmer J (eds) The environment in question. Routledge, London, pp 165-180

Costanza R, d'Arge R, de Groot R, Farber S, Grasso M, Hannon B, Limburg K et al (1997) The value of the world's ecosystem services and natural capital. Nature 387:253-260

de Shalit A (1995) Why posterity matters: environmental policies and future generations. Routledge, London

Engster D (2007) The heart of justice: care ethics and political theory. Oxford University Press, Oxford

Fagan M (2009) The inseparability of ethics and politics: rethinking the third in emmanuel levinas. Contemporary Polit Theory 8:5-22

Fagan M (2017) Who's afraid of the ecological apocalypse? Climate change and the production of the ethical subject. Br J Polit Int Relat 19:225-244

Fioramonti L (2013) Gross domestic problem: the politics behind the world's most powerful number. Zed Books, London

Giddens A (1999) Risk and responsibility. Modern Law Rev 62:1-10

Gómez-Baggethun E, Ruiz-Pérez M (2011) Economic valuation and the commodification of ecosystem services. Progr Phys Geogr Earth Env 35:613-628

Goodland R (1995) The concept of environmental sustainability. Annu Rev Ecol Syst 26:1-24

Gottlieb RS (1994) Ethics and trauma: levinas, feminism, and deep ecology. Cross Currents 44:222-240

Groves C (2014) Care, uncertainty and intergenerational ethics. Palgrave, London

Groves C (2015) The bomb in my backyard, the serpent in my house: environmental justice, risk and the colonisation of attachment. Env Polit 24:853-873

Hölscher L (1999) Die Entdeckung Der Zukunft. Fischer, Frankfurt

Honig B (2012) The politics of public things. No Found 10:59-76

Johns-Putra A (2017) Borrowing the world: climate change fiction and the problem of posterity. Metaphora 2. https://metaphora.univi e.ac.at/volume2-johns-putra.pdf

Kitchin R, Kneale J (2001) Science fiction or future fact? Exploring imaginative geographies of the new millennium. Prog Hum Geogr $25: 19-35$
Lloyd V (2008) The secular faith of gillian rose. J Relig Ethics 36:683-705

Marris P (1996) The politics of uncertainty: attachment in private and public life. Routledge, London, New York

McLaren DP (2017) Mirror, mirror: fairness and justice in climate engineering (PhD Thesis). Lancaster University, Lancaster

Naess A (1990) Ecology, community and lifestyle: outline of an ecosophy. Cambridge University Press, Cambridge

Northcott MS (2013) A political theology of climate change. William B. Eerdmans Publishing Company, Grand Rapids

Norton BG (2005) Sustainability: a philosophy of adaptive ecosystem management. University of Chicago Press, Chicago

Nussbaum MC (2003) Upheavals of thought: the intelligence of emotions. Cambridge University Press, Cambridge

O’Neill J (1993) Ecology, policy and politics. Routledge, London

Osborne P (1995) The politics of time. Verso, London

Pinchot G (1998) Breaking new ground. Island Press, Washimgton

Rose G (1993) Angry angels: simone weil and emmanuel levinas judaism and modernity: philosophical essays. Blackwell, London, pp 211-224

Rose G (1996) Mourning becomes the law : philosophy and representation. Cambridge University Press, Cambridge

Ruddick S (1980) Maternal thinking. Feminist Stud 6:342-367

Sayer A (2011) Why Things matter to people: social science, Values and ethical life. Cambridge University Press, Cambridge, New York

Schlosberg D, Carruthers D (2010) Indigenous struggles, environmental justice, and community capabilities. Glob Env Polit 10:12-35

Schneewind JB (1984) The divine corporation and the history of ethics. In: Rorty R, Schneewind JB, Skinner Q (eds) Philosophy in history: essays on the historiography of philosophy. Cambridge University Press, Cambridge, pp 173-192

Scott JC (1998) Seeing like a state: how certain schemes to improve the human condition have failed. Yale University Press, New Haven

Seymour N (2013) Strange natures: futurity, empathy, and the queer ecological imagination. University of Illinois Press, Urbana

Solow RM (1974) The economics of resources or the resources of economics. In: Gopalakrishnan C (ed) Classic papers in natural resource economics. Palgrave Macmillan, London, pp 257-276

Spellerberg IF, Fedor PJ (2003) A tribute to Claude Shannon (19162001) and a plea for more rigorous use of species richness, species diversity and the "Shannon-Wiener" Index. Glob Ecol Biogeogr 12(3):177-179. https://doi.org/10.1046/j.1466-822X.2003.00015 $\mathrm{X}$

Watson RA (1983) A critique of anti-anthropocentric biocentrism. Env Ethics 5:245-256

Winnicott DW (1991) Playing and Reality. Psychology Press, London

Publisher's Note Springer Nature remains neutral with regard to jurisdictional claims in published maps and institutional affiliations. 